\title{
Elevation of blood $\beta$-hydroxybutyrate concentration affects glucose metabolism in dairy cows before and after parturition
}

\author{
M. Zarrin, ${ }^{*} \dagger$ L. Grossen-Rösti, ${ }^{*}$ R. M. Bruckmaier, ${ }^{*}$ and J. J. Gross ${ }^{* 1}$ \\ *Veterinary Physiology, Vetsuisse Faculty, University of Bern, 3012 Bern, Switzerland \\ †Department of Animal Science, Agriculture Faculty, Yasouj University, 75918-74831 Yasouj, Iran
}

\begin{abstract}
Recent studies in mid- and late-lactation dairy cows showed that $\beta$-hydroxybutyrate (BHB) infusion had a considerable effect on glucose metabolism and immune response during intramammary lipopolysaccharide challenge. The objective of the present study was to infuse BHB during the dry period and after parturition to investigate the effects of elevated plasma BHB concentrations on metabolism and endocrine changes in transition dairy cows. The hypothesis tested was that regulation of glucose metabolism would change at different physiological stages and an additional elevation of BHB concentration would alter glucose concentration. Multiparous Holstein cows in wk -2 (antepartum, a.p.; $\mathrm{n}=6$ ) and $\mathrm{wk}+2$ (postpartum, p.p.; $\mathrm{n}=8$ ) relative to calving were infused ( $4 \mathrm{~h}$ from 0800 to $1200 \mathrm{~h}$ ) with a BHB solution to increase plasma BHB concentration to 1.5 to $2.0 \mathrm{mmol} / \mathrm{L}$ (HyperB). The same period the next day without any infusion was considered the control period $(\mathrm{CON})$. Blood samples were taken $1 \mathrm{~h}$ before the start of infusion as reference samples and every 30 min during the following $6 \mathrm{~h}(4 \mathrm{~h}$ of infusion and $2 \mathrm{~h}$ after infusion) in the HyperB and CON periods, and analyzed for glucose, BHB, insulin, and glucagon concentrations. During the steady state period (the latter $2 \mathrm{~h}$ of the 4-h infusion), plasma BHB concentration reached $1.87 \pm 0.05 \mathrm{mmol} / \mathrm{L}$ (a.p.) and $1.93 \pm 0.05$ $\mathrm{mmol} / \mathrm{L}$ (p.p.) in HyperB compared with $0.55 \pm 0.06$ $\mathrm{mmol} / \mathrm{L}$ (a.p.) and $0.64 \pm 0.04 \mathrm{mmol} / \mathrm{L}$ (p.p.) in $\mathrm{CON}$, respectively. The 4 -h average $\mathrm{BHB}$ infusion rate was $12.4 \pm 1.0$ and $13.3 \pm 0.9 \mu \mathrm{mol} / \mathrm{kg}$ of $\mathrm{BW}$ per minute in wk -2 and +2 , respectively. Infusion of BHB caused a decrease of plasma glucose concentrations relative to preinfusion levels both before and after parturition, although basal glucose concentrations were different before and after calving. Infusion of BHB increased
\end{abstract}

Received July 7, 2016.

Accepted December 7, 2016.

${ }^{1}$ Corresponding author: josef.gross@vetsuisse.unibe.ch plasma insulin concentrations a.p. but not p.p., despite a higher basal insulin concentration before than after parturition. These findings show that effects of hyperketonemia on plasma glucose concentrations are similar before and after calving but that endocrine adaptation to hyperketonemia differs before and after parturition. We assume that BHB is a metabolic key regulator in early lactating dairy cows and may affect glucose concentration by further pathways such as gluconeogenesis and altered lipolysis.

Key words: $\beta$-hydroxybutyrate, glucose, glucagon, transition period, dairy cow

\section{INTRODUCTION}

As actual energy and nutrient requirements for maintenance and milk synthesis cannot be covered by adequate feed intake, a negative energy balance (NEB) exists at the onset of lactation in high-yielding dairy cows (Drackley et al., 2001; Gross et al., 2011). During NEB in early lactation, low plasma glucose concentrations are observed and, concomitantly, concentrations of plasma free fatty acids (FFA) and subsequently ketone bodies are increased (Drackley et al., 2001; Gross et al., 2011). $\beta$-Hydroxybutyrate, the most prominent circulating ketone body in ruminants, can be used as energy source in many tissues such as brain and heart (Laffel, 1999; Veech, 2004), kidney (Weidemann and Krebs, 1969), skeletal muscle (Ruderman and Goodman, 1973), and the lactating mammary gland (Shaw, 1942). However, an elevation of plasma BHB concentration above $1.2 \mathrm{mmol} / \mathrm{L}$ indicates subclinical ketosis in dairy cows, which has detrimental effects on animal health and performance (Ospina et al., 2010). The elevation of plasma BHB concentration reduced circulating glucose concentration in ewes (Schlumbohm and Harmeyer, 2004) and increased the risk of clinical ketosis, displaced abomasum, and metritis with subsequent decrease of milk production in dairy cows (Duffield et al., 2009). Although ketone bodies may exert detrimental effects on animal health, they serve as an alternative energy source in metabolism. 
Recent studies showed that a long-term BHB infusion decreased plasma glucose and glucagon concentrations in dairy cows (Zarrin et al., 2013) and affected systemic as well as local mammary metabolism and the immune response of the mammary gland (Zarrin et al., 2014a,b). Zarrin et al. (2014a,b) assumed that the requirement for glucose by the immune system can be partially replaced by BHB.

However, the latter studies were conducted in mid- to late-lactation dairy cows. To our knowledge, no study has evaluated effects of BHB infusion on metabolism of transition dairy cows. Ketosis and its treatment are, however, significant issues in early-lactation dairy cows. The general aim of this study was to better understand the interrelationship between plasma BHB and glucose concentration. We infused BHB into late-gestation and early-lactation dairy cows to investigate the effects of elevated plasma BHB concentrations on glucose, insulin, and glucagon. The hypothesis tested was that regulation of glucose metabolism differs in different physiological stages and an additional elevation of BHB concentration beyond the metabolic adaptation observed after parturition alters glucose concentration in early lactating dairy cows during a NEB. In the long term, the outcomes of the present study could be used to develop new strategies for ketosis treatment.

\section{MATERIALS AND METHODS}

\section{Animals and Housing Conditions}

All procedures followed the Swiss Law on Animal Protection and were approved by the Committee of Animal Experiments of the Canton Fribourg, Switzerland. Eight late-gestation, multiparous Holstein dairy cows [parity number after calving in the present study: $3.4 \pm 1.8$ (range: $2-7$ ); previous lactation yield: 7,750 $\pm 1,803 \mathrm{~kg}$ (range: $5,536-11,203 \mathrm{~kg}$ ), mean $\pm \mathrm{SD}$ ] were enrolled from wk 3 before the expected calving date (a.p.) to wk 3 postpartum (p.p.). Table 1 provides data on weekly DMI, energy balance, BW, and concentrations of glucose, FFA, and BHB from wk 3 a.p. to wk 3 p.p. Approximately 2 wk before the start of the experiment, animals were adapted to housing and feeding conditions in the tiestall barn. All animals were clinically healthy, and health status was followed continuously by daily veterinary inspections and weekly clinical examination including a blood glutaraldehyde coagulation test to detect chronic infections and hepatic disorders (Sandholm, 1976).

Before parturition, cows were component fed with hay ad libitum plus $1 \mathrm{~kg}$ of cereal-based concentrate and $0.5 \mathrm{~kg}$ of mineral supplement for dry cows until calving. Thereafter, a mineral supplement for lactat-

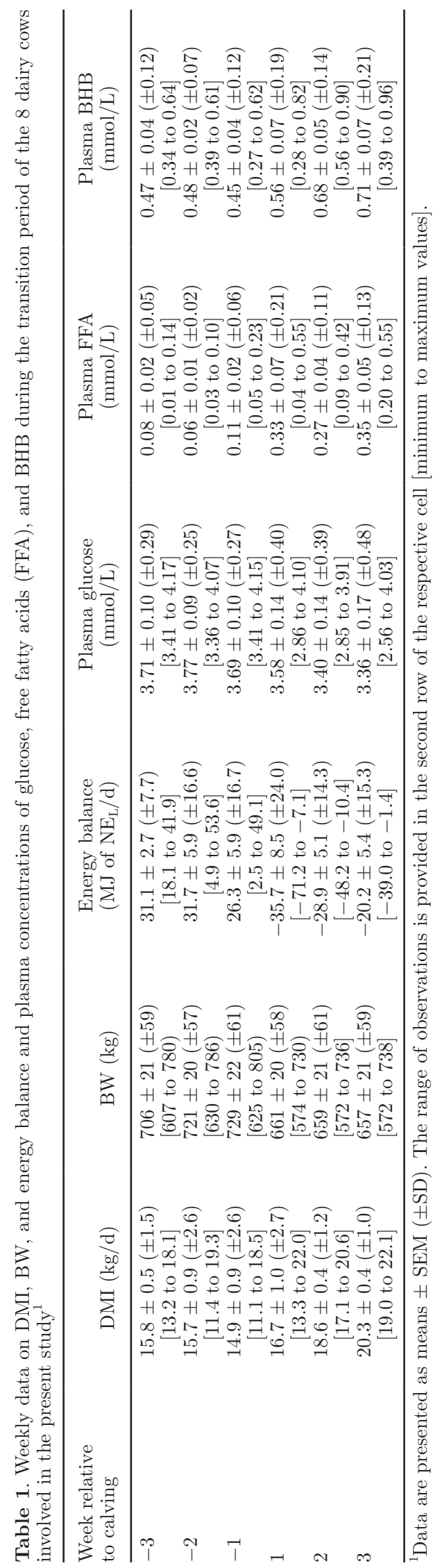


Table 2. Chemical composition and nutrient values $(\mathrm{g} / \mathrm{kg}$ of $\mathrm{DM}$ unless otherwise noted) of hay and concentrate provided during the experiment

\begin{tabular}{lcc}
\hline Nutrient & Hay & Concentrate $^{1}$ \\
\hline DM content (\%) & 88 & 89 \\
Energy content (MJ of $\mathrm{NE}_{\mathrm{L}} / \mathrm{kg}$ of DM) & 5.7 & 8.9 \\
Crude ash & 97 & 23 \\
CP & 146 & 98 \\
Absorbable protein at the duodenum & 93 & 100 \\
Crude fat & $\mathrm{ND}^{2}$ & 76 \\
Crude fiber & 246 & 26 \\
$\mathrm{Ca}$ & $\mathrm{ND}$ & 0.4 \\
$\mathrm{P}$ & $\mathrm{ND}$ & 3.2 \\
$\mathrm{Mg}$ & $\mathrm{ND}$ & 1.0 \\
$\mathrm{Na}$ & $\mathrm{ND}$ & 1.7 \\
\hline
\end{tabular}

${ }^{1}$ Concentrate consisting of $30.4 \%$ barley, $30.0 \%$ corn, $30.0 \%$ wheat, $5.6 \%$ hydrogenated vegetable fat, $3.05 \%$ molasses, $0.35 \% \beta$-carotene, $0.6 \%$ salt and mineral premix.

${ }^{2}$ Not determined.

ing cows was provided and the amount of concentrate (fed twice daily in equal portions) was adjusted every week according to the calculated energy and nutrient requirements (Agroscope, 2015). Chemical composition and nutrient values of the hay and concentrate provided are shown in Table 2. Individual feed intake and milk yield were recorded daily, and BW and milk composition were determined weekly. Energy balance (EB) was calculated as the difference between energy intake via feed and energy expenditure for maintenance and milk production (Agroscope, 2015). Water was continuously available for cows.

\section{Experimental Design and BHB Infusion}

In wk 2 a.p. ( $20.7 \pm 7.9$ d a.p., range 35 to 14 d a.p. $)$ and in wk 2 p.p. $(12.8 \pm 1.2 \mathrm{~d}$ p.p., range 11 to $14 \mathrm{~d}$ p.p.), 6 animals were intravenously infused through an indwelling catheter with $1.7 \mathrm{M}$ Na-DL- $\beta$-OH-butyrate for $4 \mathrm{~h}$ starting at $0800 \mathrm{~h}$ on $\mathrm{d} 1$ to achieve an elevated plasma BHB concentration (HyperB: 1.5 to 2.0 $\mathrm{mmol} / \mathrm{L}$, above the subclinical ketosis threshold of 1.2 $\mathrm{mmol} / \mathrm{L})$. On the next day, the same sampling period but without any infusions was designated the control period $(\mathbf{C O N})$ in the same individuals. Because BHB solution remained after the treatment of the first 6 cows, we decided to infuse 2 more cows. However, at that time no antepartum cows were available. Consequently, 2 additional cows were infused with BHB only in wk 2 p.p. Cows were fed between 0630 and $0730 \mathrm{~h}$, after the morning milking. Based on previous studies (Zarrin et al., 2013), infusion of BHB started at a rate of 12 to $13 \mu \mathrm{mol}$ of $\mathrm{BHB} /(\mathrm{kg}$ of $\mathrm{BW} \times \min )$ and was thereafter adjusted at 5 -min intervals according to the continuously determined plasma BHB concentrations. Details on the preparation of solutions and infusion procedures were explained in Zarrin et al. (2013).

\section{Blood Sampling and Analysis}

One day before the start of infusions and the control period, respectively, both jugular veins of cows were fitted with indwelling intravenous catheters $(32 \mathrm{~cm} \times 16$ gauge; Cavafix Certo Splittocan, B. Braun Melsungen AG, Germany). During the periods of BHB infusions and days without infusions, blood $(\sim 9 \mathrm{~mL}$ into tubes containing tri-potassium EDTA) was sampled from the catheter contralateral to the infusion site at 30-min intervals starting at $0800 \mathrm{~h}$. Sampling was performed during the $4 \mathrm{~h}$ of BHB infusion and continued for $2 \mathrm{~h}$ after the end of infusion until $1400 \mathrm{~h}$. For the first $2 \mathrm{~h}$ of infusion, additional blood samples $(1 \mathrm{~mL})$ were taken and analyzed immediately for $\mathrm{BHB}$ concentration to adjust the $\mathrm{BHB}$ infusion rate every 5 min. Plasma $\mathrm{BHB}$ concentrations were kept at a steady state between 2 and $4 \mathrm{~h}$ after the start of infusions. Samples were immediately placed on wet ice and centrifuged for $20 \mathrm{~min}$ $\left(3,000 \times g, 4^{\circ} \mathrm{C}\right)$, and the harvested plasma was stored at $-20^{\circ} \mathrm{C}$ until analysis.

Plasma concentrations of glucose, FFA, and BHB were measured enzymatically using an automated analyzer (Cobas Mira 2, Hoffmann-La Roche, Basel, Switzerland) and commercial kits as described by Gross et al. (2011). Plasma concentrations of insulin and glucagon were measured by RIA as described by Vicari et al. (2008) and Zarrin et al. (2013), respectively. In addition, the molar ratio of insulin to glucagon was calculated according to Muller et al. (1971).

\section{Statistical Analysis}

Statistical analysis was performed using SAS software (version 9.4, SAS Institute Inc., Cary, NC). The UNIVARIATE procedure of SAS was used to check for normal distribution of data. When variables were not normally distributed, data were log-transformed. Data presented in text and figures are means \pm SEM. Differences in basal concentrations of plasma metabolites and endocrine parameters between a.p. and p.p., and between control and infusion day in wk -2 and +2 relative to calving were evaluated using the MIXED procedure of SAS with time points (a.p., p.p.) and paired experimental days (HyperB, CON) as fixed effects. The individual cow was used as repeated subject in the statistical model. Concentrations of metabolites and endocrine parameters were considered dependent 
variables. The model was run with the variance components (VC) default setting as covariate structure and the Bonferroni correction to adjust for multiple comparisons. Significant effects were assumed at $P<0.05$.

\section{RESULTS}

\section{DMI, EB, Milk Yield, and BHB Infusion Rates}

Dry matter intake was lower in late gestation (15.7 $\pm 0.9 \mathrm{~kg} / \mathrm{d}$, wk 2 a.p.) compared with early lactation $(18.6 \pm 0.4 \mathrm{~kg} / \mathrm{d}$ in wk 2 p.p.; $P=0.03$, Table 1$)$. Energy balance decreased from $31.7 \pm 5.9 \mathrm{MJ}$ of $\mathrm{NE}_{\mathrm{L}} / \mathrm{d}$ in wk 2 a.p. to $-28.9 \pm 5.1 \mathrm{MJ}$ of $\mathrm{NE}_{\mathrm{L}} / \mathrm{d}$ in wk 2 p.p. $(P<0.001$, Table 1$)$. The average daily milk yield was $33.5 \pm 2.2 \mathrm{~kg} / \mathrm{d}$ (SD: 6.9 , range: 22.8 to $42.3 \mathrm{~kg} / \mathrm{d}$ ) in wk 2 p.p.

The BHB infusion rates summarized at 30-min intervals during the $4 \mathrm{~h}$ of infusions before and after parturition are shown in Figure 1. The average infusion rates of BHB during the steady state period from 2 to $4 \mathrm{~h}$ after the start of infusions were slightly higher $(P$ $=0.06)$ in wk 2 p.p., being $12.2 \pm 0.4$ and $13.3 \pm 0.3$ $\mu \mathrm{mol} /(\mathrm{kg}$ of $\mathrm{BW} \times \min )$ in wk 2 a.p. and wk 2 p.p., respectively. After $4 \mathrm{~h}$, infusion of BHB was stopped and sampling continued for additional $2 \mathrm{~h}$ (Figure 1). The amount of the BHB solution infused during $4 \mathrm{~h}$ did not differ between before $(1,182 \pm 57 \mathrm{~mL})$ and after parturition $(1,302 \pm 80 \mathrm{~mL}, P=0.09)$. The target BHB concentration during the steady state period was 1.87 \pm 0.06 and $1.93 \pm 0.05 \mathrm{mmol} / \mathrm{L}$ (in wk 2 a.p. and wk 2 p.p., respectively, Figure 2, $P=0.51$ ). Plasma BHB concentration decreased after the end of infusion and reached preinfusion levels faster in wk 2 p.p. than in wk 2 a.p. (1 vs. $1.5 \mathrm{~h}$ after infusion stop; Figure 2, $P$ $=0.02)$. No effects of the individual cow and parity number on infusion characteristics a.p. or p.p. were observed.

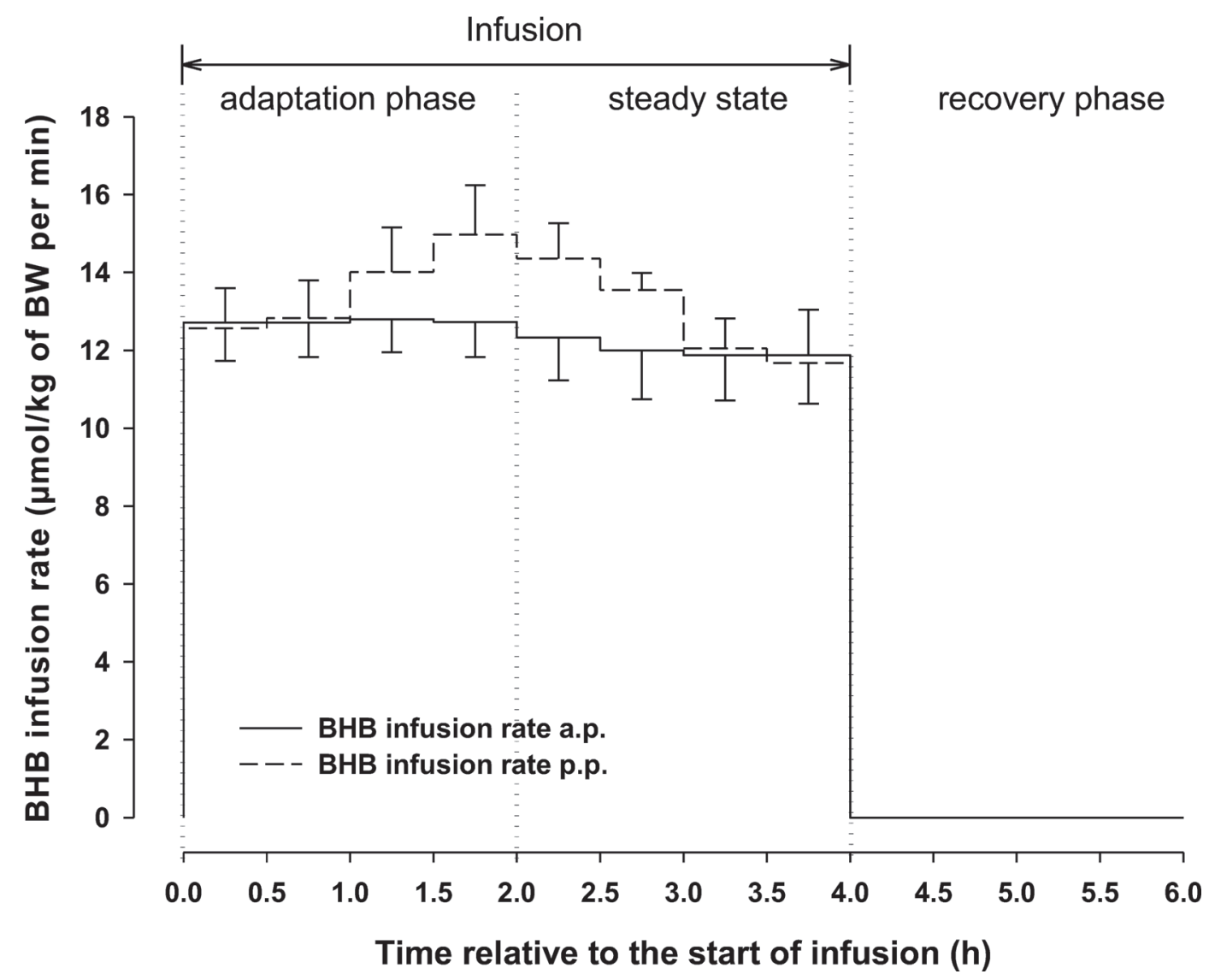

Figure 1. Infusion rates of BHB during the 4-h infusion period in wk 2 before parturition (antepartum, a.p., $\mathrm{n}=6$, solid line) and in wk 2 after parturition (postpartum, p.p., $\mathrm{n}=8$, dashed line). Data represent mean infusion rates (mean \pm SEM) at 30-min intervals during the adaptation phase ( 0 to $2 \mathrm{~h}$ relative to the start of infusion), the steady state period ( 2 to $4 \mathrm{~h}$ relative to the start of infusion), and the recovery phase (infusion rate $=0 ; 4$ to $6 \mathrm{~h}$ relative to the start of infusion). 


\section{Changes in Plasma Metabolites and Endocrine Parameters During Lactational Stages and $B H B$ Infusions}

Plasma BHB concentration was higher before the start of infusions in wk 2 p.p. $(0.76 \pm 0.05 \mathrm{mmol} / \mathrm{L})$ compared with wk 2 a.p. $(0.50 \pm 0.05 \mathrm{mmol} / \mathrm{L}, P=$ $0.004)$, whereas glucose concentration was lower p.p. $(3.17 \pm 0.14$ vs. $3.64 \pm 0.13 \mathrm{mmol} / \mathrm{L}, P=0.04)$. Insulin but not glucagon concentrations in plasma were higher in wk 2 a.p. $(19.6 \pm 3.2 \mu \mathrm{U} / \mathrm{mL}$ and $155.3 \pm 14.4 \mathrm{pg} /$ $\mathrm{mL}$, respectively) compared with wk 2 p.p. $(6.5 \pm 0.8$ $\mu \mathrm{U} / \mathrm{mL}, P<0.001$, and $136.4 \pm 10.6 \mathrm{pg} / \mathrm{mL}, P=0.30$, respectively). The molar ratio of insulin:glucagon was higher before parturition (3.09 \pm 0.63$)$ compared with after parturition $(1.14 \pm 0.15, P<0.001)$. Observations reflected the expected changes in dairy cows during transition from late pregnancy to early lactation.

Due to the BHB infusion, plasma glucose concentration decreased by $0.44 \pm 0.09 \mathrm{mmol} / \mathrm{L}$ in wk 2 a.p. $(P$ $<0.01)$ and by $0.55 \pm 0.07 \mathrm{mmol} / \mathrm{L}$ in wk 2 p.p. $(P$ $<0.001)$. The extent of the decline in plasma glucose concentration did not differ between wk 2 a.p. and wk 2 p.p. $(P=0.41)$. After the end of BHB infusions, plasma glucose concentrations recovered within $1.5 \mathrm{~h}$ and $1 \mathrm{~h}$ in wk 2 a.p. and wk 2 p.p., respectively (Figure 3).
Plasma insulin concentration increased only during BHB infusion before parturition $(P=0.01)$ but not after parturition $(P=0.64$, Figure 4$)$. Infusion of BHB did not affect plasma glucagon concentration in wk 2 a.p. or in wk 2 p.p. ( $P=0.45$ and $P=0.16$, respectively; Figure 5). During the steady state period (between 2 and $4 \mathrm{~h}$ of BHB infusion), the molar insulin:glucagon ratio was elevated in wk 2 a.p. $(P=0.03)$ but unaffected in wk 2 p.p. $(P=0.92$, Figure 6$)$.

\section{DISCUSSION}

\section{Effects of Stage of Lactation and BHB Infusion on Glucose Concentration}

Ketone bodies, and BHB in particular, are known to be involved in the expression of subclinical and clinical ketosis, to depress feed intake, and to negatively affect fertility in dairy cows (Duffield et al., 2009; Ospina et al., 2010; Laeger et al., 2010; Raboisson et al., 2014). Recent studies on BHB infusions were shown to affect gluconeogenesis and the immune system. However, the studies of Zarrin et al. (2013) were carried out in midto late-lactation dairy cows to increase plasma BHB during a period of energetic equilibrium. The present study aimed to better define glucose homeostasis in
A

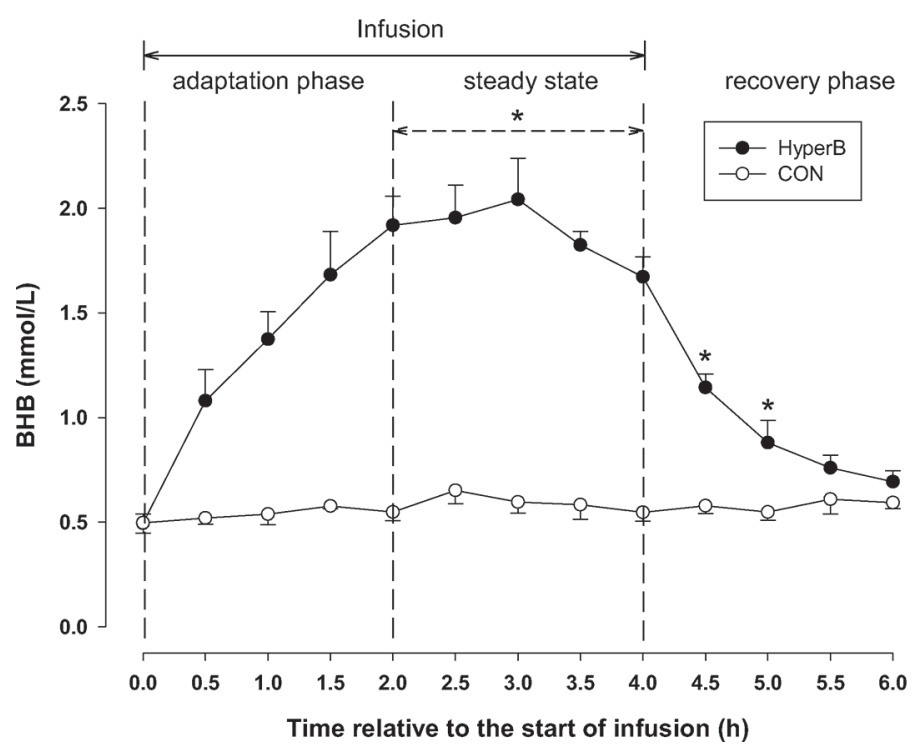

B

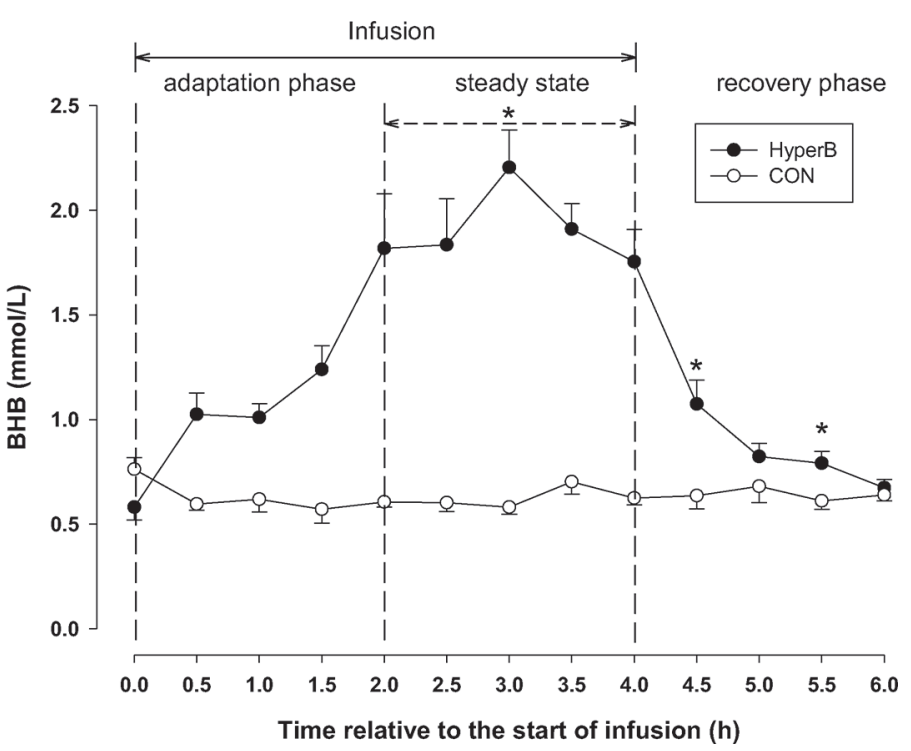

Figure 2. Plasma BHB concentration in cows with BHB infusion (HyperB) and on a day without infusion (CON) in wk 2 before parturition $(\mathrm{A} ; \mathrm{n}=6)$ and wk 2 after parturition $(\mathrm{B} ; \mathrm{n}=8)$. Data represent mean values $\pm \mathrm{SEM}$ during the adaptation phase $(0$ to $2 \mathrm{~h}$ relative to the start of infusion), the steady state period ( 2 to $4 \mathrm{~h}$ relative to the start of infusion), and the recovery phase (infusion rate $=0 ; 4$ to $6 \mathrm{~h}$ relative to the start of infusion). ${ }^{*} P<0.05$ : differences between HyperB and CON during the steady state period, and differences between HyperB and CON at single time points during the recovery phase. 
A

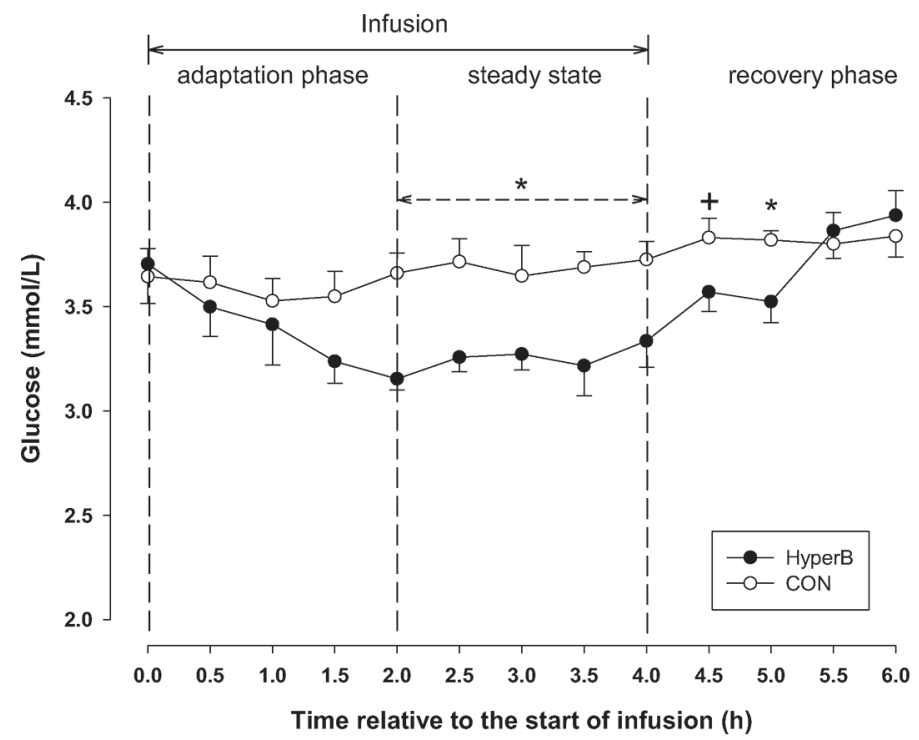

B

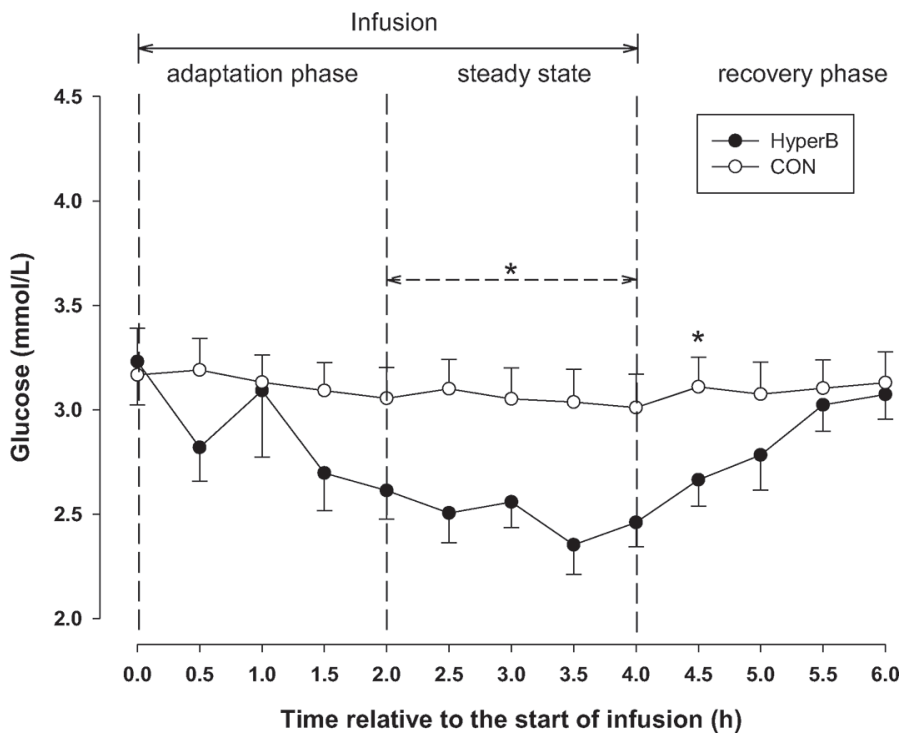

Figure 3. Plasma glucose concentration in cows with BHB infusion (HyperB) and on a day without infusion (CON) in wk 2 before parturition $(\mathrm{A} ; \mathrm{n}=6)$ and wk 2 after parturition $(\mathrm{B} ; \mathrm{n}=8)$. Data represent mean values \pm SEM during the adaptation phase $(0$ to $2 \mathrm{~h}$ relative to the start of infusion), the steady state period ( 2 to $4 \mathrm{~h}$ relative to the start of infusion), and the recovery phase (infusion rate $=0 ; 4$ to $6 \mathrm{~h}$ relative to the start of infusion). ${ }^{*} P<0.05$ : differences between HyperB and CON during the steady state period: ${ }^{*} P<0.05$ and $+P<0.10$ : differences between HyperB and CON at single time points during the recovery phase.

transition dairy cows exposed to elevated BHB concentrations. We investigated the effects of infused BHB on metabolic and endocrine adaptation of dairy cows during the dry period (i.e., during late gestation in the absence of nutrient requirements for milk production) and in early gestation (i.e., during NEB caused by high milk production and simultaneous inadequate feed intake). We hypothesized that the regulation of glucose
A

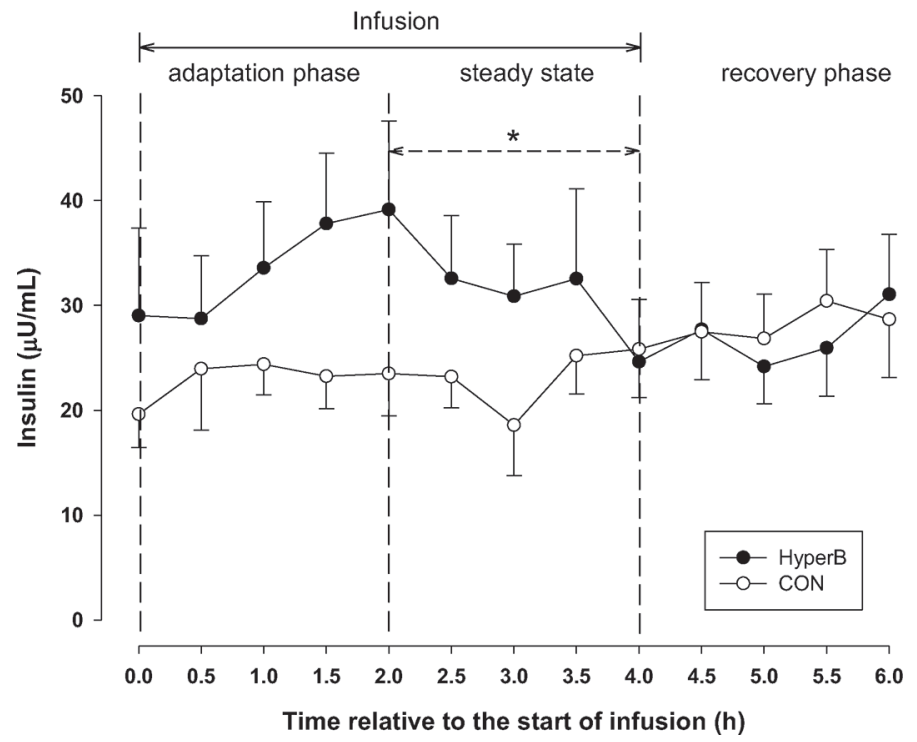

B

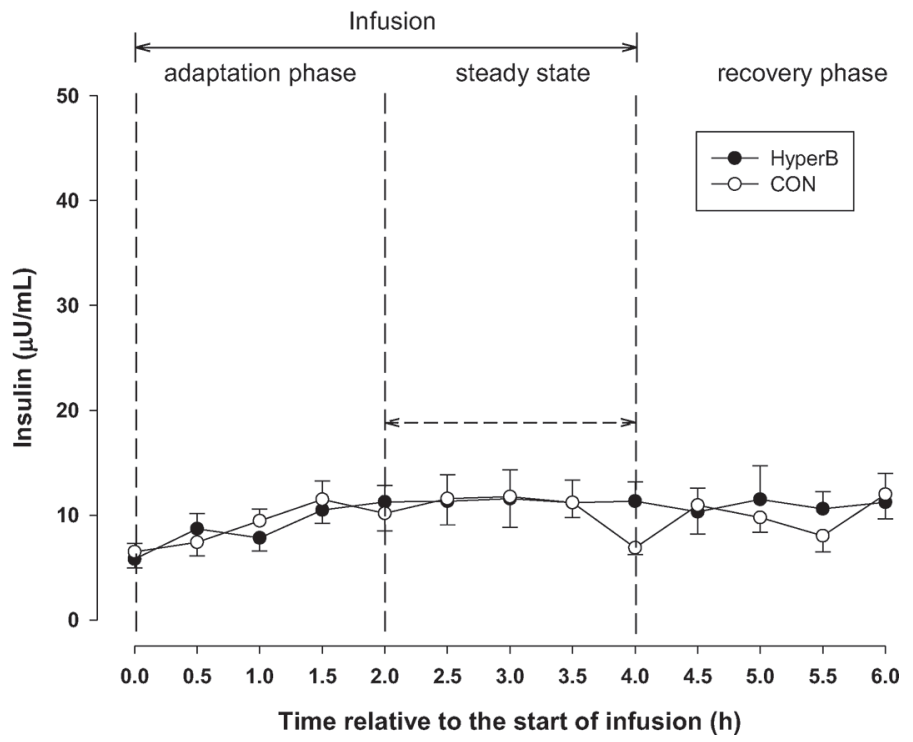

Figure 4. Plasma insulin concentration in cows with BHB infusion (HyperB) and on a day without infusion (CON) in wk 2 before parturition $(\mathrm{A} ; \mathrm{n}=6)$ and wk 2 after parturition $(\mathrm{B} ; \mathrm{n}=8)$. Data represent mean values \pm SEM during the adaptation phase $(0$ to $2 \mathrm{~h}$ relative to the start of infusion), the steady state period ( 2 to $4 \mathrm{~h}$ relative to the start of infusion), and the recovery phase (infusion rate $=0 ; 4$ to $6 \mathrm{~h}$ relative to the start of infusion). ${ }^{*} P<0.05$ : differences between HyperB and CON during the steady state period. 
A

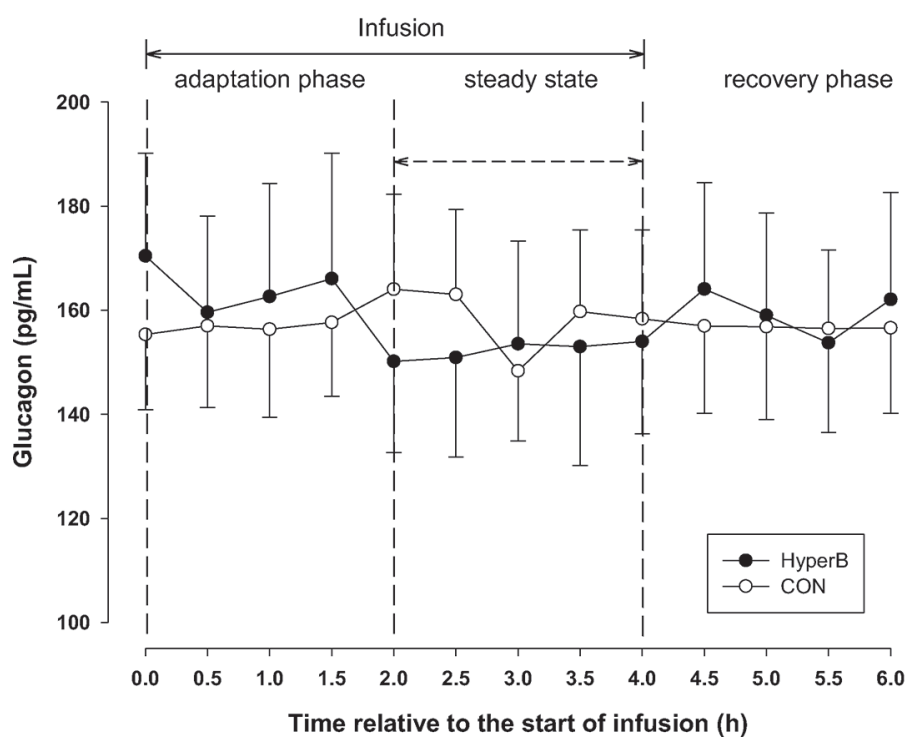

B

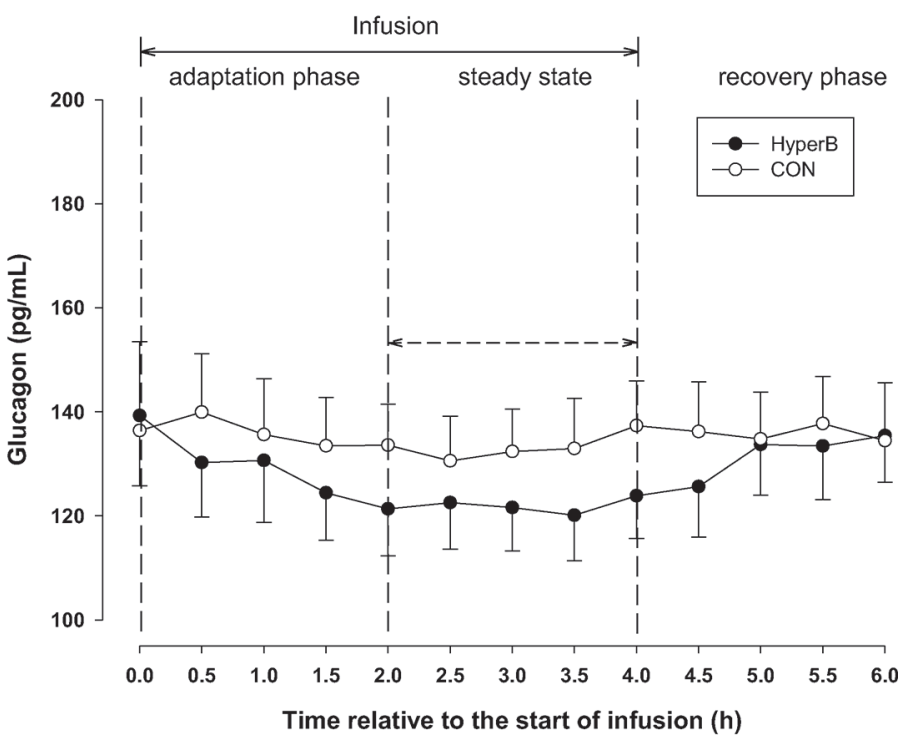

Figure 5. Plasma glucagon concentration in cows with BHB infusion (HyperB) and on a day without infusion (CON) in wk 2 before parturition $(\mathrm{A} ; \mathrm{n}=6)$ and wk 2 after parturition $(\mathrm{B} ; \mathrm{n}=8)$. Data represent mean values \pm SEM during the adaptation phase $(0$ to $2 \mathrm{~h}$ relative to the start of infusion), the steady state period ( 2 to $4 \mathrm{~h}$ relative to the start of infusion), and the recovery phase (infusion rate $=0 ; 4$ to $6 \mathrm{~h}$ relative to the start of infusion).

homeostasis changes at different physiological stages, and that an additional elevation of BHB beyond the metabolic adaptation after parturition might change glucose concentration in early-lactation dairy cows.
The present study revealed commonalities but also differences in adaptation responses to BHB infusion in dry and early-lactation cows. Infusion of BHB directly depicts a nutrient source whose immediate availability
A

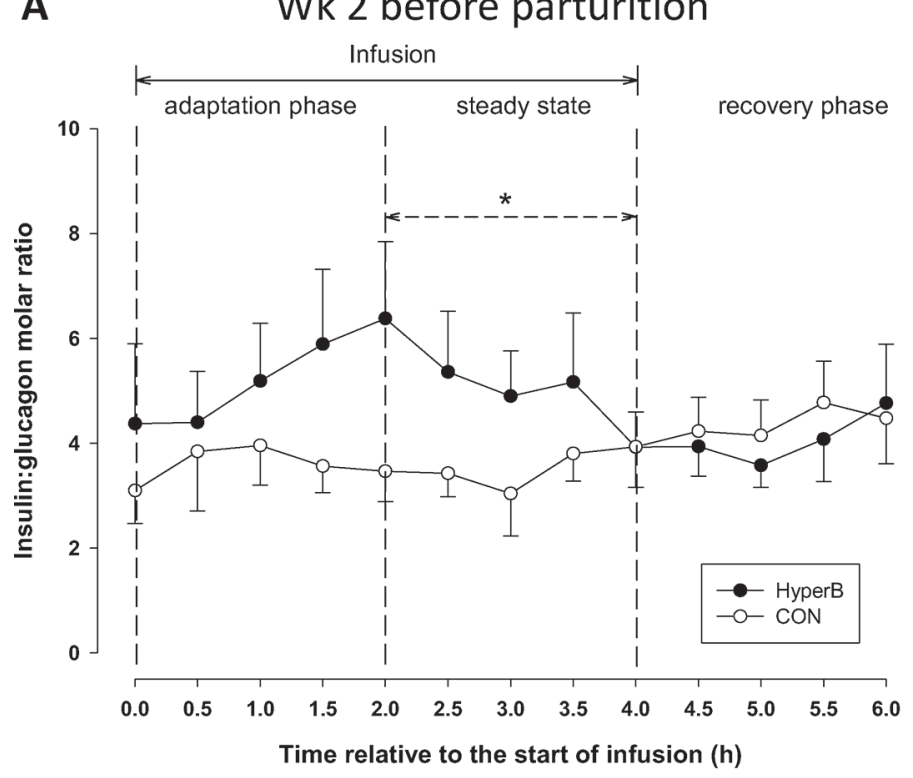

B

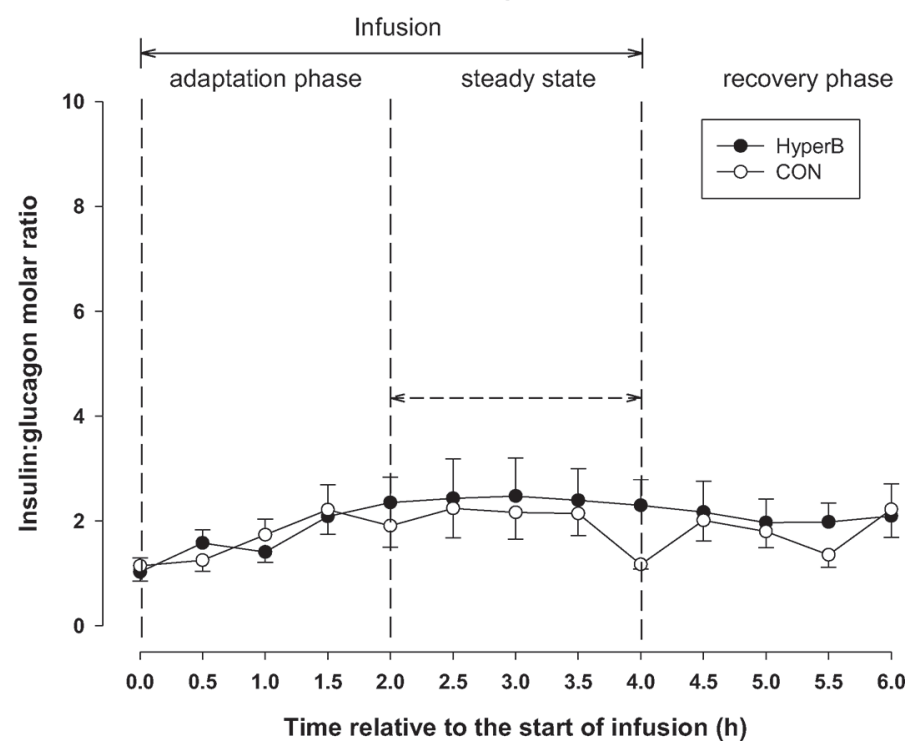

Figure 6. The molar insulin:glucagon ratio in plasma of cows with BHB infusion (HyperB) and on a day without infusion (CON) in wk 2 before parturition $(A ; n=6)$ and wk 2 after parturition $(B ; n=8)$. Data represent mean values \pm SEM during the adaptation phase $(0$ to $2 \mathrm{~h}$ relative to the start of infusion), the steady state period ( 2 to $4 \mathrm{~h}$ relative to the start of infusion), and the recovery phase (infusion rate $=0 ; 4$ to $6 \mathrm{~h}$ relative to the start of infusion). ${ }^{*} P<0.05$ : differences between HyperB and CON during the steady state period. 
requires adjustments in fuel homeostasis to manage the short-term surplus of nutrients. The target concentration of BHB maintained during the steady state phase of infusions in wk 2 a.p. and wk 2 p.p. was above the threshold of 1.2 to $1.4 \mathrm{mmol} / \mathrm{L}$ indicating subclinical ketosis (Duffield et al., 2009; Ospina et al., 2010) but similar to results obtained in mid- to late-lactation dairy cows conducted by Zarrin et al. (2013). The observed changes in basal concentrations of plasma metabolites and hormones (elevated BHB, lower glucose, glucagon, and insulin concentrations after parturition compared with late gestation) in the present study are in agreement with previous reports on transition dairy cows (Drackley et al., 2001; Gross et al., 2011). However, it must be emphasized that the present observations are derived from a limited number of animals. As we placed catheters the day before infusions to avoid additional stress on the infusion day and to obtain all necessary samples to adjust for infusion rates, we decided to perform the infusion of BHB on the first day after catheterization. As we have observed in other infusion experiments, the risk of clotting and involuntary removal of catheters increases the longer catheters are placed. Therefore, we kept the catheter inside the animal for the minimal amount of time and obtained control samples after the actual infusions. Baseline values of the same animal before infusions could also be used for the comparison with the infusion period in case the catheters could not be maintained over $2 \mathrm{~d}$. Although we did not see effects of the previous infusion day on parameters investigated on the following day, a longer BHB infusion period might have a more sustainable effect. The elevation of BHB for a short time as in the present study might have different effects compared with long-term exposure of an animal's metabolism to BHB due to insufficient FFA oxidation, as commonly observed in early lactating dairy cows.

The clearest effect of BHB infusion was the decline in plasma glucose concentration within $1.5 \mathrm{~h}$ in both pre- and postpartum lactational stages. This finding confirmed our earlier reports in mid-lactation dairy cows infused with BHB (Zarrin et al., 2013) and is consistent with observations on decreased plasma glucose concentrations associated with elevated $\mathrm{BHB}$ via infusion in other species than cattle; for instance, in pregnant sheep (Schlumbohm and Harmeyer, 2003, 2004) and pigs (Müller et al., 1984). Based on the present results, it seems that the BHB effect on plasma glucose concentration occurs consistently in cows of different lactational stages.

Zarrin et al. (2013, 2014a,b) assumed that inhibition of gluconeogenesis via reduced glucagon concentrations due to BHB infusion in mid-lactation dairy cows resulted in a partial replacement of glucose by BHB as energy source for lactation, peripheral tissues, and the immune system. Hence, the inevitable question on the fate of a surplus of BHB supply in transition dairy cows arose. Dry cows in late gestation in the present study were in positive $\mathrm{EB}$, whereas after parturition fresh lactating cows experienced a marked energy and nutrient deficiency. The high glucose demand for lactose, and consequently milk synthesis, in early-lactation cows is commonly thought to cause low plasma glucose concentrations in addition to the insufficient rates of gluconeogenesis to meet glucose demands after parturition (Aschenbach et al., 2010). Although a reduced gluconeogenesis rate due to BHB is not unlikely, further potential effects of BHB and endocrine changes during the transition period on glycogenolysis, fatty acid, and amino acid breakdown must also be considered.

Adipose tissue, liver, and the mammary gland may act differently upon a surplus of ketone bodies depending on their endocrine responsiveness. Huhtanen et al. (1993) found that ruminally infused butyrate and subsequent ketogenesis caused reduced gluconeogenesis and hypoglycemia in ruminants. In humans, therapeutic ketone body infusion is known to reduce glucose production and consequently circulating glucose concentrations in diabetic patients (Kesl et al., 2016). Interestingly, the extent of decline in plasma glucose concentration following BHB infusion was similar before and after calving, but glucose concentration decreased further despite its already low concentration. Despite a higher basal BHB concentration p.p., however, infusion rate and total amount of BHB infused tended to be higher after parturition than in late gestation. Weber et al. (2013) observed that hepatic glycogen concentrations were higher in dry cows $15 \mathrm{~d}$ before parturition than in early-lactation cows at $14 \mathrm{~d}$ p.p. Our observations on the comparable changes of glucose concentration due to BHB infusions in wk -2 and +2 relative to calving further suggest that gluconeogenesis rather than glycogen turnover are affected by hyperketonemia.

\section{Effects of BHB Infusions on Insulin Concentrations and Tissue Responsiveness}

In the present study, insulin concentration was increased during BHB infusion only before parturition; postpartum, insulin is known to be secreted at a much lower rate and peripheral tissues become refractory toward insulin to ensure a prioritized nutrient supply for the lactating mammary gland (Bell, 1995; De Koster and Opsomer, 2013). Before parturition, peripheral tissues, including adipose, can be assumed to be in an anabolic state (McNamara et al., 2016) and responsive toward insulin (De Koster and Opsomer, 2013). However, a NEB and mobilization of adipose tissue may 
already exist before parturition. Recently, Mátis et al. (2015) showed that butyrate increases pancreatic insulin secretion and affects insulin receptor expression in chicken. Yan and Ajuwon (2015) investigated the activation of the AMP-activated protein kinase (AMPK) signaling pathway by butyrate, resulting in reduced lipolysis of adipocytes. Furthermore, butyrate stimulated adiponectin expression and glucose uptake into adipocytes, and triggered triglyceride formation and accumulation (Yan and Ajuwon, 2015). We assume that BHB infusion stimulated insulin secretion during the infusion before parturition. Butler et al. (2003) found that greater insulin concentrations in early-lactation dairy cows also inhibited lipolysis and decreased FFA concentration in plasma. During the nonlactating state of animals in the current study, before parturition with a positive EB, the infused BHB represented a surplus of nutrients that were not needed. Although we did not measure FFA during the BHB infusion, we can speculate that lipolysis was inhibited, at least before parturition, due to increased insulin following BHB infusion. Although it seems unlikely that butyrate from rumen fermentation contributes to the increased plasma BHB concentration during the short-term infusions, the excess energy in the circulation in terms of BHB provided by infusion affects the control of energy homeostasis. Laeger et al. (2010) and Rojas-Morales et al. (2016) reported that BHB is a signal for abundant energy that concomitantly reduces feed intake. At least prepartum, the elevated plasma insulin concentration during BHB infusion in the present study could contribute to lowering plasma glucose beyond reduced lipolysis by formation of body fat reserves, as shown previously by Newman and Verdin (2014) and Coomans et al. (2011). $\beta$-Hydroxybutyrate itself can be used as an alternative energy source in various tissues, as reported previously (Veech, 2004; Zarrin et al., 2013). However, looking closer at the adaptation phase during BHB infusion in the present study, the decline in plasma glucose concentration a.p. occurred approximately $30 \mathrm{~min}$ before the increase of insulin. According to previous studies, elevated ketone body concentrations exert only a narrow effect on insulin secretion in ruminants (Jordan and Phillips, 1978; Heitmann and Fernandez, 1986).

In sheep and mid-lactation dairy cows, changes in insulin concentration did not explain the glucose decline during elevated BHB concentrations (Schlumbohm and Harmeyer, 2003; Zarrin et al., 2013). Instead, insulin was shown to suppress glucose production through inhibition of regulatory enzymes involved in gluconeogenesis (Brockman and Laarveld, 1986; Huhtanen et al., 1993; Hayirli, 2006). Direct inhibitory effects of BHB on gluconeogenesis of lactating dairy cows at the posttranscriptional level were suggested by Zarrin et al. (2013). The rate of gluconeogenesis predominantly mediated by glucagon was reduced by BHB infusion in mid-lactation dairy cows (Zarrin et al., 2013). Despite the low activity of gluconeogenic enzymes and low rate of gluconeogenesis directly after parturition resulting in low plasma glucose concentrations (Aschenbach et al., 2010), the additional BHB elevation through infusion further decreased glucose concentration in the present study. Subclinical and clinical cases of ketosis occurring in early lactation might further reduce and limit glucose availability. However, the present findings relied on a limited number of animals. Further investigations are needed to clarify potential differences between a "naturally" occurring ketosis and effects of ketone bodies provided via infusion.

In agreement with literature reports, our plasma glucagon concentrations were higher before parturition than after parturition. Contrary to our previous findings (Zarrin et al., 2013) in mid-lactation cows, glucagon concentration was not affected by BHB infusion in dry cows and was only slightly reduced during the BHB infusion period in early-lactation cows in the present study, possibly due to a lack of statistical power. We can only speculate as to whether more animal observations would have improved the significance level for glucagon differences in early lactation. Although ketone bodies have been shown to reduce glucagon concentrations in some species (Gerich et al., 1974, 1976; Goberna et al., 1974), the concomitant physiological state of the animal seems to affect adaptation of glucagon concentration. Glucagon has a ketogenic effect when present at high concentrations (Williamson et al., 1969; Alberti et al., 1978). In cases of low insulin concentrations, as in early-lactation dairy cows, glucagon has a stimulatory effect on lipolysis (Alberti et al., 1978). The inhibitory effect of BHB on lipolysis (as discussed earlier for dry cows in positive energy balance) in early lactation can be speculated to additionally decrease glucagon in early lactation.

Ketone body infusion decreases peripheral glucose utilization in nonruminants (Neptune et al., 1961; Williamson and Krebs, 1961; Mebane and Madison, 1962). Although BHB administration in pregnant sheep decreased glucose production by inhibition of hepatic gluconeogenesis, utilization of available glucose was not affected (Schlumbohm and Harmeyer, 2004). Likewise, early-lactation dairy cows in the present study exposed to a NEB with limited availability of glucose that was further depressed by BHB infusion immediately used the supplementary BHB, as indicated by a tendency toward a higher infusion rate and amount of BHB applied compared with that in late-gestation cows (i.e., in the a.p. period) to achieve the same target concentration. Independent of the insulin resistance in peripheral tis- 
sues of early-lactation cows (De Koster and Opsomer, 2013), the high energetic requirements for maintenance (including the immune system) and lactation support the utilization of ketone bodies as an alternative energy source. Most likely, our observations on reduced glucose concentrations during elevated $\mathrm{BHB}$ concentrations can be explained by decreased gluconeogenesis. Further research is warranted to elucidate the effect of ketone bodies on pathways involved in glucose homeostasis such as glycogen formation, glycogenolysis, and gluconeogenesis.

\section{CONCLUSIONS}

A decline in plasma glucose concentration was observed following BHB infusion in both pre- and postpartum transition dairy cows. In both periods, this effect was not identically mediated by insulin and glucagon. The exacerbation of hypoglycemia by exogenous BHB after parturition supposes its intrinsic regulatory ability in glucose metabolism. A possibly increased clearance of BHB after parturition assumes adaptation of numerous tissues involved in lipid and carbohydrate metabolism. Most likely, our observations on reduced glucose concentrations during elevated BHB concentrations can be explained by decreased gluconeogenesis.

\section{ACKNOWLEDGMENTS}

L. Grossen-Rösti was supported by a scholarship of the H. Wilhelm Schaumann-Stiftung (Hamburg, Germany).

\section{REFERENCES}

Agroscope. 2015. Fütterungsempfehlungen und Nährwerttabellen für Wiederkäuer (Grünes Buch). Online ed. Agroscope Institute for Livestock Sciences, Posieux, Switzerland. Accessed April 2016. http://www.agroscope.admin.ch/futtermitteldatenbank/04834/ index.html?lang $=$ de.

Alberti, K. G., D. G. Johnston, A. Gill, A. J. Barnes, and H. Orskov. 1978. Hormonal regulation of ketone-body metabolism in man. Biochem. Soc. Symp. 43:163-182.

Aschenbach, J. R., N. B. Kristensen, S. S. Donkin, H. M. Hammon, and G. B. Penner. 2010. Gluconeogenesis in dairy cows: The secret of making sweet milk from sour dough. IUBMB Life 62:869-877. https://doi.org/10.1002/iub.400.

Bell, A. W. 1995. Regulation of organic nutrient metabolism during transition from late pregnancy to early lactation. J. Anim. Sci. 73:2804-2819. (Review)

Brockman, R. P., and B. Laarveld. 1986. Effect of insulin on gluconeogenesis and the metabolism of lactate in sheep. Can. J. Physiol. Pharmacol. 64:1055-1059.

Butler, S. T., A. L. Marr, S. H. Pelton, R. P. Radcliff, M. C. Lucy, and W. R. Butler. 2003. Insulin restores GH responsiveness during lactation-induced negative energy balance in dairy cattle: effects on expression of IGF-I and GH receptor 1A. J. Endocrinol. 176:205-217.
Coomans, C. P., J. J. Geerling, B. Guigas, A. M. van den Hoek, E. T. Parlevliet, D. M. Ouwens, H. Pijl, P. J. Voshol, P. C. Rensen, L. M. Havekes, and J. A. Romijn. 2011. Circulating insulin stimulates fatty acid retention in white adipose tissue via KATP channel activation in the central nervous system only in insulin-sensitive mice. J. Lipid Res. 52:1712-1722. https://doi.org/10.1194/jlr.M015396.

De Koster, J. D., and G. Opsomer. 2013. Insulin resistance in dairy cows. Vet. Clin. North Am. Food Anim. Pract. 29:299-322. https://doi.org/10.1016/j.cvfa.2013.04.002.

Drackley, J. K., T. R. Overton, and G. N. Douglas. 2001. Adaptations of glucose and long-chain fatty acid metabolism in liver of dairy cows during the periparturient period. J. Dairy Sci. 84:E100-E112.

Duffield, T. F., K. D. Lissemore, B. W. McBride, and K. E. Leslie. 2009. Impact of hyperketonemia in early lactation dairy cows on health and production. J. Dairy Sci. 92:571-580. https://doi. org/10.3168/jds.2008-1507.

Gerich, J. E., M. A. Charles, and G. M. Grodsky. 1974. Characterization of the effects of arginine and glucose on glucagon and insulin release from the perfused rat pancreas. J. Clin. Invest. 54:833-841.

Gerich, J. E., M. A. Charles, and G. M. Grodsky. 1976. Regulation of pancreatic insulin and glucagon secretion. Annu. Rev. Physiol. 38:353-388.

Goberna, R., J. Tamarit Jr., J. Osorio, R. Fussgänger, J. Tamarit, and E. F. Pfeiffer. 1974. Action of B-hydroxy butyrate, acetoacetate and palmitate on the insulin release in the perfused isolated rat pancreas. Horm. Metab. Res. 6:256-260.

Gross, J., H. A. van Dorland, R. M. Bruckmaier, and F. J. Schwarz. 2011. Performance and metabolic profile of dairy cows during a lactational and deliberately induced negative energy balance with subsequent realimentation. J. Dairy Sci. 94:1820-1830. https:// doi.org/10.3168/jds.2010-3707.

Hayirli, A. 2006. The role of exogenous insulin in the complex of hepatic lipidosis and ketosis associated with insulin resistance phenomenon in postpartum dairy cattle. Vet. Res. Commun. 30:749-774.

Heitmann, R. N., and J. M. Fernandez. 1986. Autoregulation of alimentary and hepatic ketogenesis in sheep. J. Dairy Sci. 69:12701281.

Huhtanen, P., H. Miettinen, and M. Ylinen. 1993. Effect of increasing ruminal butyrate on milk yield and blood constituents in dairy cows fed a grass silage-based diet. J. Dairy Sci. 76:1114-1124.

Jordan, H. N., and R. W. Phillips. 1978. Effect of fatty acid on isolated ovine pancreatic islets. Am. J. Physiol. 234:E162-E167.

Kesl, S. L., A. M. Poff, N. P. Ward, T. N. Fiorelli, C. Ari, A. J. Van Putten, J. W. Sherwood, P. Arnold, and D. P. D'Agostino. 2016. Effects of exogenous ketone supplementation on blood ketone, glucose, triglyceride, and lipoprotein levels in Sprague-Dawley rats. Nutr. Metab. (Lond.) 13:9 https://doi.org/10.1186/s12986-0160069-y.

Laeger, T., C. C. Metges, and B. Kuhla. 2010. Role of beta-hydroxybutyric acid in the central regulation of energy balance. Appetite 54:450-455. https://doi.org/10.1016/j.appet.2010.04.005.

Laffel, L. 1999. Ketone bodies: A review of physiology, pathophysiology and application of monitoring to diabetes. Diabetes Metab. Res. Rev. 15:412-426.

Mátis, G., A. Kulcsár, V. Turowski, H. Fébel, Z. Neogrády, and K. Huber. 2015. Effects of oral butyrate application on insulin signaling in various tissues of chickens. Domest. Anim. Endocrinol. 50:26-31. https://doi.org/10.1016/j.domaniend.2014.07.004.

McNamara, J. P., K. Huber, and A. Kenéz. 2016. A dynamic, mechanistic model of metabolism in adipose tissue of lactating dairy cattle. J. Dairy Sci. 99:5649-5661. https://doi.org/10.3168/jds.20159585 .

Mebane, D., and L. L. Madison. 1962. The hypoglycemic effect of ketone bodies. J. Clin. Invest. 41:1383. (Abstr.)

Müller, M. J., U. Paschen, and H. J. Seitz. 1984. Effect of ketone bodies on glucose production and utilization in the miniature pig. J. Clin. Invest. 74:249-261.

Muller, W. A., G. R. Faloona, and R. H. Unger. 1971. The influence of the antecedent diet upon glucagon and insulin secretion. N. Engl. J. Med. 285:1450-1454. 
Neptune, E. M., Jr., H. C. Sudduth, F. J. Fash, and J. J. Jr. Reish. 1961. Metabolism of betahydroxybutyrate and acetoacetate by exercised rat diaphragm and diaphragm homogenate. Am. J. Physiol. 201:235-238.

Newman, J. C., and E. Verdin. 2014. Ketone bodies as signaling metabolites. Trends Endocrinol. Metab. 25:42-52. https://doi. org/10.1016/j.tem.2013.09.002.

Ospina, P. A., D. V. Nydam, T. Stokol, and T. R. Overton. 2010. Evaluation of nonesterified fatty acids and beta-hydroxybutyrate in transition dairy cattle in the northeastern United States: Critical thresholds for prediction of clinical diseases. J. Dairy Sci. 93:546-554. https://doi.org/10.3168/jds.2009-2277.

Raboisson, D., M. Mounié, and E. Maigné. 2014. Diseases, reproductive performance, and changes in milk production associated with subclinical ketosis in dairy cows: A meta-analysis and review. J. Dairy Sci. 97:7547-7563. https://doi.org/10.3168/jds.2014-8237.

Rojas-Morales, P., E. Tapia, and J. Pedraza-Chaverri. 2016. $\beta$-Hydroxybutyrate: A signaling metabolite in starvation response? Cell. Signal. 28:917-923. https://doi.org/10.1016/j. cellsig.2016.04.005.

Ruderman, N. B., and M. N. Goodman. 1973. Regulation of ketone body metabolism in skeletal muscle. Am. J. Physiol. 224:13911397.

Sandholm, M. 1976. Coagulation of serum by glutaraldehyde. Clin. Biochem. 9:39-41.

Schlumbohm, C., and J. Harmeyer. 2003. Hypocalcemia reduces endogenous glucose production in hyperketonemic sheep. J. Dairy Sci. 86:1953-1962.

Schlumbohm, C., and J. Harmeyer. 2004. Hyperketonemia impairs glucose metabolism in pregnant and nonpregnant ewes. J. Dairy Sci. $87: 350-358$.

Shaw, J. C. 1942. A comparison of acetone body metabolism of the lactating mammary gland of the normal cow with that of the cow with ketosis. J. Biol. Chem. 142:53-60.

Veech, R. L. 2004. The therapeutic implications of ketone bodies: The effects of ketone bodies in pathological conditions: ketosis, ketogenic diet, redox states, insulin resistance, and mitochondrial metabolism. Prostaglandins Leukot. Essent. Fatty Acids 70:309-319.
Vicari, T., J. J. G. C. van den Borne, W. J. J. Gerrits, Y. Zbinden, and J. W. Blum. 2008. Postprandial blood hormone and metabolite concentrations influenced by feeding frequency and feeding level in veal calves. Domest. Anim. Endocrinol. 34:74-88.

Weber, C., C. Hametner, A. Tuchscherer, B. Losand, E. Kanitz, W. Otten, S. P. Singh, R. M. Bruckmaier, F. Becker, W. Kanitz, and H. M. Hammon. 2013. Variation in fat mobilization during early lactation differently affects feed intake, body condition, and lipid and glucose metabolism in high-yielding dairy cows. J. Dairy Sci. 96:165-180. https://doi.org/10.3168/jds.2012-5574.

Weidemann, M. J., and H. A. Krebs. 1969. The fuel of respiration of rat kidney cortex. Biochem. J. 112:149-166.

Williamson, J. R., E. T. Browning, R. G. Thurman, and R. Scholz. 1969. Inhibition of glucagon effects in perfused rat liver by $(+)$ decanoylcarnitine. J. Biol. Chem. 244:5055-5064.

Williamson, J. R., and H. A. Krebs. 1961. Acetoacetate as fuel of respiration in the perfused rat heart. Biochem. J. 80:540-547.

Yan, H., and K. M. Ajuwon. 2015. Mechanism of butyrate stimulation of triglyceride storage and adipokine expression during adipogenic differentiation of porcine stromovascular cells. PLoS One 10:e0145940. https://doi.org/10.1371/journal.pone.0145940.

Zarrin, M., L. De Matteis, M. C. M. B. Vernay, O. Wellnitz, H. A. van Dorland, and R. M. Bruckmaier. 2013. Long-term elevation of $\beta$-hydroxybutyrate in dairy cows through infusion: Effects on feed intake, milk production, and metabolism. J. Dairy Sci. 96:29602972. https://doi.org/10.3168/jds.2012-6224.

Zarrin, M., O. Wellnitz, H. A. van Dorland, and R. M. Bruckmaier. 2014a. Induced hyperketonemia affects the mammary immune response during lipopolysaccharide challenge in dairy cows. J. Dairy Sci. 97:330-339. https://doi.org/10.3168/jds.2013-7222.

Zarrin, M., O. Wellnitz, H. A. van Dorland, J. J. Gross, and R. M. Bruckmaier. 2014b. Hyperketonemia during LPS induced mastitis affects systemic and local intramammary metabolism in dairy cows. J. Dairy Sci. 97:3531-3541. https://doi.org/10.3168/ jds.2013-7480. 